\section{Tropical Journal of Pathology and Microbiology}

2020 Volume 6 Number 7 September-October

\title{
A study on evaluation of the role of fine-needle aspiration cytology in the etiology of lymphadenopathy in the rural population attending tertiary care hospital
}

\author{
Sitalata C. ${ }^{1}$, Kalyan K. ${ }^{2 *}$ \\ DOI: https://doi.org/10.17511/jopm.2020.i07.02
}

\footnotetext{
1 Sitalata C., Associate Professor, Department of Pathology, Maharaja Institute of Medical Sciences, Vizianagaram, Andhra Pradesh, India.

2* Kalyan K., Professor, Department of Pathology, Dr. Pinnamaneni Siddhartha Institute of Medical Sciences and Research Foundation, Gannavaram, Andhra Pradesh, India.
}

Introduction: Lymph nodes are a site for organized collections of lymphoreticular tissue and are pink-gray bean-shaped encapsulated organs. Lymph nodes are among the commonly aspirated organs for diagnostic purposes. Lymphadenopathy is of great clinical significance as underlying diseases may range from a treatable infectious etiology to malignant neoplasms Fine needle aspiration cytology (FNAC) is a reliable as well as an inexpensive method used to diagnose lymphadenopathy of various sites. Aims: To evaluate the usefulness of FNAC as a diagnostic tool in the etiological causes of lymphadenopathy and to study the cytomorphological features associated with various lymphadenopathies. Materials and Methods: The present prospective study was carried out in the Department of Pathology at Maharajah's Institute of Medical Sciences, Vizianagaram, a Tertiary Care Centre. A total of 210 patients of all age groups underwent FNAC of enlarged lymph nodes during this study period. Results: FNAC diagnosis was found to be as follows: tubercular lymphadenitis in 98 cases $(46.67 \%)$ followed by reactive hyperplasia in 35 cases (16.67\%), metastatic carcinoma 29 (13.8\%), granulomatous lymphadenitis 27 (12.85\%), nonspecific lymphadenitis 8 (3.8\%), acute suppurative lymphadenitis 7 (3.33\%) and lymphoma 4 (1.8). Conclusion: FNAC of lymph nodes is an excellent first-line investigation to determine the nature of the lesion. It is quick, safe, minimally invasive, and reliable and is readily accepted by the patient.

Keywords: Fine needle aspiration cytology (FNAC), Lymph node, Lymphadenopathy, Tuberculous lymphadenitis, Malignant neoplasms

Corresponding Author

Kalyan K., Professor, Department of Pathology, Dr. Pinnamaneni Siddhartha Institute of Medical Sciences and Research Foundation, Gannavaram, Andhra Pradesh, India.

Email: medcompass360@gmail.com
How to Cite this Article

To Browse
Sitalata C, Kalyan K. A study on evaluation of the role of fine-needle aspiration cytology in the etiology of lymphadenopathy in the rural population attending tertiary care hospital. Trop J Pathol Microbiol. 2020;6(7):425-429.

Available From

https://pathology.medresearch.in/index.php/jopm/ar ticle/view/483

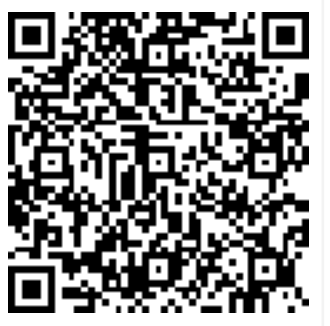




\section{Introduction}

Lymph nodes are a site for organized collections of lymphoreticular tissue and are pink-gray beanshaped encapsulated organs. They are located at anatomically constant points along the course of lymphatic vessels. The common sites of distribution are cervical, axillary, mediastinal, retroperitoneal, iliac, and inguinal regions. Lymphadenopathy is the most common clinical presentation in outpatient department patients which consists of various etiological factors ranging from inflammatory to a malignant condition [1]. The most common cause of peripheral lymphadenopathy in our setting is an inflammatory reaction to a microbial challenge, followed by lymphomas and malignant metastatic deposits.

The common etiological factors for lymphadenopathy tend to be considered as reactive, tuberculous, or malignant metastases. Overall, infective conditions (reactive and tuberculous) are responsible for the majority of lesions. M. tuberculosis is the most common cause of granulomatous lymphadenitis in India [2-4]. Fineneedle aspiration cytology (FNAC) is a clinical technique used to obtain cells, tissues, and/or fluid through a thin needle attached with a disposable syringe for the diagnosis of masses [5]. Lymph node aspiration is of great value in diagnosing lymphadenitis, lymphomas, and metastatic carcinoma [6].

Aspiration of lymph nodes for diagnostic purposes was first done by Griey and Gray in 1904, in patients with sleeping sickness [7]. Lymph nodes are among the commonly aspirated organs for diagnostic purposes [8]. In 1927, Dudgeon and Patrick were the first to use FNAC in diagnosing tuberculous lymphadenitis [9]. De May has summarized the advantages of FNAC with the acronym SAFE means Simple, Accurate, Fast, and Economical [10]. The diagnostic yield of FNAC can be improved if it is accompanied by radiological guidance like ultrasonography and computed tomography scan [11].

In 1847, Kun had done the pioneering act of first time reporting the use of aspiration biopsy. Since then fine needle aspiration cytology (FNAC) has been a rapid, simple, safe, reliable minimally invasive, and inexpensive method of establishing the diagnosis of lesions and masses in various sites and organs and is the most convenient bedside diagnostic aid $[12,13,14,15,16]$.
Drawbacks of FNAC also exist like sampling error in the form of improper technique, micrometastasis, benign epithelial inclusions, partial lymph node involvement by lesion, and a very small lymph node where sampling is difficult, also a high incidence of false results [6].

\section{Materials and Methods}

Type of study: Prospective study

Place and Duration of Study: This prospective study was carried out in the Department of Pathology at Maharajah's Institute of Medical Sciences, Vizianagaram for a period of one year from March 2017 to March 2018.

Sample size: A total of 210 patients of all age groups underwent FNAC of enlarged lymph nodes during this study period.

Inclusion criteria: All patients presenting with lymph node enlargement were included in the study.

Exclusion criteria: Those patients with aspirated material were either inadequate or smears were unsatisfactory for evaluation and a known case of malignancy were excluded from this study.

Sample collection and method: After obtaining the Ethical Committee Clearance from our institution, Patients age, sex, site, duration were noted and full clinical examination to look out for other node enlargement were noted. FNAC was performed after taking consent and explaining the procedure to the patient. FNAC was done using a 5$10 \mathrm{ml}$ disposable syringe with a 22-24 gauge needle. Two-three passes were done in all patients and four smears were made for each site of aspiration.

Two smears were fixed immediately in isopropyl alcohol and stained with Papanicolaou (Pap) stain and Hematoxylin \& Eosin (H\&E) and the other two were air-dried stained with Giemsa stain and where ever tuberculosis was suspected the Ziehl Nelson (ZN) stain was done. Cytomorphological findings like cell population, areas of necrosis, and pattern were assessed by examination under low power, high power, and oil immersion.

Statistical analysis: Statistical analysis was performed by the SPSS program for Windows, version 17.0 (SPSS, Chicago, Illinois). Categorical variables are presented as absolute numbers and percentages. 


\section{Results}

A total of 1100 cases were aspirated in the cytopathology section over one year from March 2017 to March 2018, out of which 210 (19.1\%) cases were lymph node FNACs. Out of 210 patients with palpable lymphadenopathy, in two cases the FNAC was inconclusive due to unsatisfactory smear preparation. There were $86(40.95 \%)$ female and $124(59.05 \%)$ male patients with the age of the patients ranged from 1 to 80 years. The maximum number of cases falling in the range between $21-40$ years ( 128 cases, $60.95 \%$ ), followed by $40-80$ years (63 cases, $30.01 \%$ ) and 19 cases $(9.04 \%)$ in the range of $0-10$ years.

Among common cytological lesions found in our study were tubercular lymphadenitis 98 cases $(46.67 \%)$ followed by reactive hyperplasia 35 cases (16.67\%), metastatic carcinoma 29 (13.8\%), granulomatous lymphadenitis 27 (12.85\%), nonspecific lymphadenitis $8(3.8 \%)$, acute suppurative lymphadenitis 7 (3.33\%) and lymphoma 4 (1.8).

\section{Table-1: Cytological diagnosis of lymphadenopathy.}

lymphadenopathy.
\begin{tabular}{|l|l|l|}
\hline \multicolumn{1}{|c|}{ Cytologic diagnosis } & Number of cases & Percentage \\
\hline Tubercular lymphadenitis & 98 & 46.67 \\
\hline Reactive hyperplasia & 35 & 16.67 \\
\hline Granulomatous lymphadenitis & 29 & 13.8 \\
\hline Metastatic carcinoma & 27 & 12.85 \\
\hline Non-specific lymphadenitis & 8 & 3.8 \\
\hline Suppurative lymphadenitis & 7 & 3.33 \\
\hline Hodgkins lymphoma & 3 & 1.4 \\
\hline Non Hodgkins lymphoma & 1 & 0.4 \\
\hline Unsatisfactory & 2 & 0.9 \\
\hline Total & 210 & \\
\hline
\end{tabular}

The lymph node aspirates were found to be diagnosed as tubercular lymphadenitis based on the presence of epithelioid cell granulomas and caseous necrosis with or without Langhan's giant cells or ZN positivity. Among these, 60 cases were ZiehlNelson staining positive. Further cytomorphologic patterns in tubercular lymphadenitis as follows.

Table-2: Correlation of cytomorphological features in TB lymphadenitis with AFB positivity.

\begin{tabular}{|l|c|c|}
\hline \multicolumn{1}{|c|}{ Cytomorphological features } & $\begin{array}{c}\text { No. of cases } \\
(\%)\end{array}$ & $\begin{array}{c}\text { AFB } \\
\text { positivity }\end{array}$ \\
\hline $\begin{array}{l}\text { Epithelioid cell granulomas without caseous } \\
\text { necrosis }\end{array}$ & $26(26.53 \%)$ & $9(15 \%)$ \\
\hline
\end{tabular}

\begin{tabular}{|l|l|l|}
\hline $\begin{array}{l}\text { Epithelioid cell granulomas with caseous } \\
\text { necrosis }\end{array}$ & $\begin{array}{l}58 \\
(59.18 \%)\end{array}$ & $14(23.3 \%)$ \\
\hline Caseous necrosis without granulomas & 14 & $37(61.67 \%)$ \\
\hline Total & $(14.28 \%)$ & \\
\hline
\end{tabular}

Granulomatous lymphadenitis was diagnosed based on the presence of epithelioid cell granuloma with or without giant cells and the absence of necrosis. Suppurative lymphadenitis cases showed predominantly polymorphonuclear leukocytes, necrotic debris, and other lymphoid cells.

\section{Discussion}

FNAC forms an important tool to aid in the diagnosis of lymphadenopathy. Lymphadenopathy is one of the commonest clinical presentations of various disease processes presents inside the body. This study was carried out to find out the relative frequencies of various etiology factors presenting as lymphadenopathy in different age groups and cytomorphological changes in the different lesions.

Among the age group which was studied range from 1-80 years with maximum cases ranged 21-40 years which is comparable with those of Shreshtha et al [17], A. B. Pandav et al [18], and A. K. Kochhar et al [13]. In our study, a male preponderance was noted and similar male preponderance was correlated with Hirachand et al [19] and Shreshtha et al [17].

Tuberculous lymphadenitis was the most common lesion and was reported in 98 cases (46.67\%) which correlated with the study by Ruchi $\mathrm{K}$ et al [20] (52.3\%) and A B Pandav et al [18] (50.53\%).

In our study cytomorphological pattern was Epithelioid cell granulomas with caseous necrosis $(59.18 \%)$ in the present study, which is closely comparable with Goswami et al [21] (50\%). AFB positivity was maximum with necrosis without granulomas pattern (61.67\%) followed by epithelioid cell granulomas with necrosis pattern $(23.3 \%)$ which correlated with findings of Goswami et al. [21].

The second most common cytological diagnosis was reactive hyperplasia was seen in 35 cases (16.67\%). Similar findings were also observed in A $\mathrm{K}$ Kochhar et al [13]. Granulomatous Iymphadenitis was seen in 29 cases $(13.8 \%)$ correlates with studies by Hirachand et al [19] (9.2\%). Granulomatous lymphadenitis can be classified as non-infectious and infectious. 
Non-infectious causes include sarcoidosis and sarcoid-like reaction.

Infectious causes can be classified as suppurative and non-suppurative. Suppurative granulomatous disorders include tularemia, cat scratch disease, Yersinia, etc. Non-suppurative granulomatous disorders include tuberculosis, BCG, toxoplasma, lepra bacilli, brucellosis, syphilis [22].

In our study lymph node aspirates in 27 cases $(12.85 \%)$ showed metastatic deposits that correlate with the studies by Malukani K (16.6\%) [23] \& Mandakini M Patel et al (27.06\%) [24]. The most common age group affected in a metastatic tumor, in the present study was 41-50 years which correlates with another study of A.K. Kochhar et al [13].

The current study reported $4(1.8 \%)$ cases of lymphoma which correlated with findings of Abdul Haque Khan et al [25] (2\%). Though their prevalence is low, they pose a great diagnostic challenge.

\section{Conclusion}

FNAC is a simple, low-cost, non-invasive and inexpensive method that can be done in various sites in the body at the same time as a useful diagnostic tool in determining the nature of enlargement of lymph nodes.

FNAC helps in the etiology of lymph node enlargement as reactive change, infective/inflammatory, lymphoma, metastatic, etc.

\section{What does the study add to the existing knowledge}

The present study concluded that FNAC in the diagnosis of lymphadenopathy was sensitive, specific, and accurate. In the current study, tuberculous lymphadenitis was recorded as the most common presentation of lymphadenopathy.

This study also highlights the usefulness of FNAC as a viable method of investigation for lymphadenopathy.

\section{Author's contributions}

Dr. C. Sitalata: Concept, study design

Dr. K. Kalyan: Manuscript preparation

\section{Reference}

01. Pandit AA, Candes FP, Khubchandani SR. Fine needle aspiration cytology of lymph nodes. J Postgrad Med. 1987;33(3)134-136.

Available from: [Article] [Crossref]

02. Indian Council of Medical Research. Tuberculosis in India - A sample survey, 1955-58. Special Report Series No- 34, New Delhi. 1959. [Crossref]

03. Dandapat MC, Mishra BM, Dash SP, Kar PK. Peripheral lymph node tuberculosis- A review of 80 cases. Br J Surg. 1990;77(8)911-912. doi: $10.1002 /$ bjs.1800770823 [Crossref]

04. Jawahar MS, Sivasubramanian S, Vijayan VK, Ramakrishnan CV, Paramasivan CN, Selvakumar $\mathrm{V}$, et al. Short course chemotherapy for tuberculous lymphadenitis in children. BMJ. 1990;301(6748)359-62. doi: $10.1136 / \mathrm{bmj} .301 .6748 .359$ [Crossref]

05. Orell SR, Sterrett GF, Walters MN, Whitaker D. Introduction- Manual and atlas of fine needle aspiration cytology, 3rd ed. New York- Churchill Livingstone. 1999;P-2-16.

[Crossref]

06. Vimal S. Dharwadkar A, Chandanwale SS, Vishwanathan V, Kumar H. Cytomorphological study of lymph node lesions- A study of 187 cases. Med J D Y Patil Univ.

2016;9(1)43-50. doi: 1987/33/3/134/5275 [Crossref]

07. Cohen MB, Miller TR, Bottles K. Classics in cytology- note on fine needle aspiration of the lymphatic glands in sleeping sickness. Acta Cytol. 1986;30(4)451-452.

[Crossref]

08. Mohanty R, Wilkinson A. Utility of Fine Needle Aspiration Cytology of Lymph nodes. IOSR J Dent Med Sci. 2013;8(5)13-18.

[Crossref]

09. Guthrie CG. Gland puncture as a diagnostic measure. John Hopkins Bull. 1921;32;266-269. [Crossref]

10. $\mathrm{Wu} \mathrm{M}$, Burstein DE. Fine needle aspiration. Cancer Invest. 2004;22(4)620-628. doi: $10.1081 / \mathrm{cnv}-200027160$ [Crossref] 
11. Simo R, Leslie A. Differential diagnosis and management of neck lumps. Surg Int. $2008 ; 24(9) 312-322$.

doi: $10.1053 /$ j.mpsur.2006.07.006 [Crossref]

12. Pavithra $P$, Geetha JP. Role of fine needle aspiration cytology in the evaluation of the spectrum of lymph node lesions. Int J Pharm Bio Sci. 2014;5(4)377-384.

doi: $10.17511 /$ jopm.2017.i3.22 [Crossref]

13. Kochchar Ak, Duggal G, Singh K, Kochchhar SK. Spectrum of cytological findings in patients with lymphadenopathy in rural population of South Haryana, India - Experience in a tertiary care hospital. Internet J Pathol. 2012;13;8.

[Crossref]

14. Behm FG, O'Dowd GJ, Frable WJ. Fine-needle aspiration effects on benign lymph node histology. Am J Clin Pathol. 1984;82(2)195-198. doi: 10.1093/ajcp/82.2.195 [Crossref]

15. Gupta AK, Nayar M, Chandra M. Reliability and limitations of fine needle aspiration cytology of lymphadenopathies- An analysis of 1,261 cases. Acta Cytol. 1991;35(6)777-783.

[Crossref]

16. Steel BL, Schwartz MR, Ramzy I. Fine needle aspiration biopsy in the diagnosis of lymphadenopathy in 1,103 patients, Role, limitations and analysis of diagnostic pitfalls. Acta Cytol. 1995;39(1)76-81.

[Crossref]

17. Shrestha D, Thapa P, Dahal M. Tuberculous and Non-tuberculous Cervical Lymphadenitis- A clinical Review. Nepalese J ENT Head Neck Surg. 2010;1(2)12-13.

doi: $10.3126 /$ njenthns.v1i2.4757 [Crossref]

18. Pandav AB, Patil PP, Lanjewar DN. Cervical lymphadenopathy - Diagnosis by FNAC, A study of 219 cases. Asian J Med Res. 2012;1(3)79-83. Available at [Article] [Crossref]

19. Hirachand S, Lakhey M, Akhter J, Thapa B. Evaluation of fine needle aspiration cytology of lymph nodes in Kathmandu Medical College, Teaching Hospital. Kathmandu Univ Med J (KUMJ). 2009;7(26)139-142.

doi: $10.3126 /$ kumj.v7i2.2707 [Crossref]
20. Khajuria R, Goswami KC, Singh K, Dubey VK. Pattern of Lymphadenopathy on Fine Needle Aspiration Cytology in Jammu. J $\mathrm{K}$ Sci. 2006;8(3).

[Crossref]

21. Goswami HM, Parikh UR, Barot HP, Vaghela GM, Yadav KS, Vegad MM. Efficacy of Fine Needle Aspiration Cytology, Ziehl-Neelsen (Z-N) Stain and Culture (Bactec) In Diagnosis Of Tuberculosis Lymphadenitis. Int J Microbiol Res. 2012;4(7)275-278.

[Crossref]

22. Asano S. Granulomatous Iymphadenitis. J Clin Exp Hematopathol. 2012;52(1)1-15.

doi: 10.9735/0975-5276.4.7.275-278 [Crossref]

23. Nikethan B, Neethu GV, Hiremath SS, Patil SB. Role of fine needle aspiration cytology in the evaluation of the etiology of lymph adenopathy. Indian J Pathol Oncol. 2016;3(4)548-551.

[Crossref]

24. atel $M M$, Italiya $S L$, Dhandha ZB, Dudhat $R B$, Kaptan KR, Shah MB, et al. Study of metastasis in lymph nodes in FNAC- our institutional experience. Int Res Med Sci. 2013;1(4)451454.

doi: $10.5455 / 2320-6012 . i j r m s 20131128$ [Crossref]

25. Khan $A H$, Hayat AS, Baloch $G H$, Jaffery $M H$, Soomro MA, Siddiqui S. Study on the role of fine needle aspiration cytology in cervical lymphadenopathy. World Applied Sci J. 2011;12(11)1951-1954.

[Crossref] 